\title{
Use of information and communication technologies in social work institutions in extraordinary circumstances
}

\author{
Enisa Hodžić ${ }^{1}$, Sabina Baraković ${ }^{1}$, Anesa Kavazović ${ }^{2}$ Jasmina Baraković Husić3 \\ ${ }^{1}$ University of Sarajevo, Faculty of Traffic and Communications, Zmaja od Bosne 8, Sarajevo, 71000, Bosnia and Herzegovina \\ ${ }^{2}$ Public Institution “Center for Social Work Tešanj”, Kralja Tvrtka 10, Tešanj, 74260, Bosnia and Herzegovina \\ ${ }^{3}$ University of Sarajevo, Faculty of Electrical Engineering, Zmaja od Bosne bb, Sarajevo, 71000, Bosnia and Herzegovina
}

\begin{abstract}
Information-Communication Technologies (ICTs) are currently used in various fields and there are many amazing inventions that are already present and make communication and life easier for us on a daily basis. The use of ICTs is less represented in the social work institutions. Therefore, this paper presents the implementation of ICTs through the chatbot application for the needs of social work created on the Tidio platform and within the webpage of the Public Institution "Center for Social Work Tešanj”. The application facilitates the work of social workers in collecting information from the users and eases the aid received by the users of social care in terms of faster responses to inquiries during emergencies, such as the COVID-19 pandemic, but also after. For the purpose of this research, an end-user survey was created and conducted with the aim of collecting user opinions on the acceptance and motivation for the use of chatbots in social work institutions. The results showed good acceptance and usage motivation of social work chatbot.
\end{abstract}

Keywords: chatbot, covid-19, ICT, pandemic, social, work

\section{Introduction}

Extraordinary circumstances in our history happened several times. For example, in the last century, humanity experienced the Spanish Flu in 1918, the Great Depression in early 30s, the Second World Ware from 1939 to 1945 , and in early 2020 the SARS-Cov-2 virus pandemic. The COVID-19 pandemic forced us to physical distancing and quarantine measures. However, in opposite to the ones prior to it, this pandemic happened in an era of intensive digital and information-communication technologies (ICTs) development and usage, which eased the living in this period. In order to maintain business, school, entertainment, and many other activities, we have utilized the ICTs and shifted from offline activities to increased online ones [1].

As given in [2], in COVID-19 pandemic as an extraordinary situation, digital technology so far has been mainly used in educational category, i.e., face-to-face to online communicating, delivering instructions, and learning. In terms of daily use, the most prominent activities were tracing, analyzing data, predicting/forecasting, and diagnosing the virus. The area where ICTs were the most represented is the public health.
Also, in work and daily living domain, it very much blended personal and professional boundaries at the expense of decreasing the risk of burnout.

On a global scale, the technology has evolved quickly in a few decades and due to pandemic it is intensively used in many areas. In addition to medical and health companies, retailers, governments, banks, education sector, etc., the social work should be one of the domains where the ICTs are deployed in order to ease the work with the ones in need of their services, but which now is challenged due to pandemic.

One of the ways to intensify the usage of ICTs in social work institutions in extraordinary circumstances, which require remote work and physical distancing, is to include chatbot technology in their activities. Chatbot is a computer program that uses information from users' input in natural language and based on that returns back to them smart and related answer [3]. In other words, these systems are mimicking the unstructured conversations or conversations specific to human-to-human interaction [4] [5].

In order to promote the ICTs usage and contribute to the field of social work in these challenging times, this 
paper aims to design and create simple social work chatbot application and to investigate its acceptance and willingness to use it in a concrete social work institution. The application facilitates the work of social workers in collecting information from the users and eases the aid received by the users of social care in terms of faster responses to inquiries during emergencies such as the COVID-19 pandemic, but also after it.

The rest of the paper is structured as follows. Section 2 provides a brief review of related work, i.e., the use of ICTs in social work field. Section 3 gives a description of design and implementation of social work chatbot. Section 4 describes the procedure of conducting the user survey on acceptance and motivation to use the designed and implemented chatbot and discusses obtained results. The last section, i.e., Section 5, concludes the paper and proposes the directions for future work.

\section{Related Work}

This section gives a brief review of the literature addressing the usage of technology in social work practice. The use of ICTs in social work interventions has been addressed by several authors in [6]-[29].

These works describe the potentials and challenges of using ICTs in social work practice [7] [8], such as speed of response, use of Internet, etc. [9] and stresses the need of social work practitioners to understand the new medium such as blogs, social networks, etc. [10]. Also, there are guides and papers dealing mainly with application of ICTs in practice processes, administration, or education [11][13]. In addition, literature addresses standards [14] and ethical guides [15]-[18] for social workers.

In general, social workers perform activities which include [19]: i. earning an education, ii. finding employment, iii. taking and story client notes, iv. conducting counselling session, v. broadly disseminating information, vi. researching resources, vii. business operations and management. All these activities can be implemented by the different level of ICTs usage incorporated. For example, with little or without ICTs, which makes them online versions; by including ICTs up to a certain extent in a way that it would be impossible to perform the activity without technology; and fully ICTs dependent activities where practitioner's role is minimal.

Studies from the first group (small engagement of ICTs) mostly encompass web trainings [20], counselling [21], or online support groups [22]. Studies addressing social workers activities which are based on ICTs (second group), cover the use of photographs [23], digital production [24], virtual reality [25], social media [26], and crowd-based platforms for sharing [27]. Lastly, studies dealing with ICTs dependent activities cover computer applications [28] and artificial intelligence (AI) [29].
The previously reviewed literature addresses the use of ICTs in social work environment in emergency situations up to a limited extent. The reason for that lies in the fact that the world has not met the crisis such as COVID-19 pandemic with this level of ICTs development and inclusion. It is expected that the analyses of ICTs usage in this domain in pandemic are to be drafted and published in the following years.

Moreover, according to the represented literature overview and the authors' best knowledge, so far there have been no studies addressing the usage of chatbot technology in particular in social workers practice, especially in emergency situations such as pandemic. This paper aims to contribute to research community in this area.

In current pandemic circumstances, text-based chatbots have been successfully deployed at scale for multiple use cases for rapid response and recovery across different sectors. They can have an immediate impact in relieving stress points, meet existing customer service requirements and solve new problems brought about by COVID-19 pandemic [30].

\section{Design and Implementation of Social Work Chatbot}

\section{A. Chatbot Design}

The social work chatbot has been created in order to serve as a guidance to the social care users by utilizing a set of questions. This chatbot has been incorporated in the wordpress webpage of Public Institution "Center for Social Work Tešanj” that we have also created, but we will refrain from providing more details on the matter. Visual appearance of the webpage is given in Figure 1. For realization we have used Tidio [31]. Tidio offers many popular languages (German, English, Spanish, Korean, Polish, Russian, Turkish, Swedish, Romanian, Portuguese, Persian, Japanese, Italian, Indian, Hebrew, French, Dutch, Danish, Chinese, and Arabic) and is the only chatbot system that offers other languages. Tidio does not have Bosnian language available, but it can be selected as the chatbot language although there are no translated chatbots available, as is the case for the above languages.

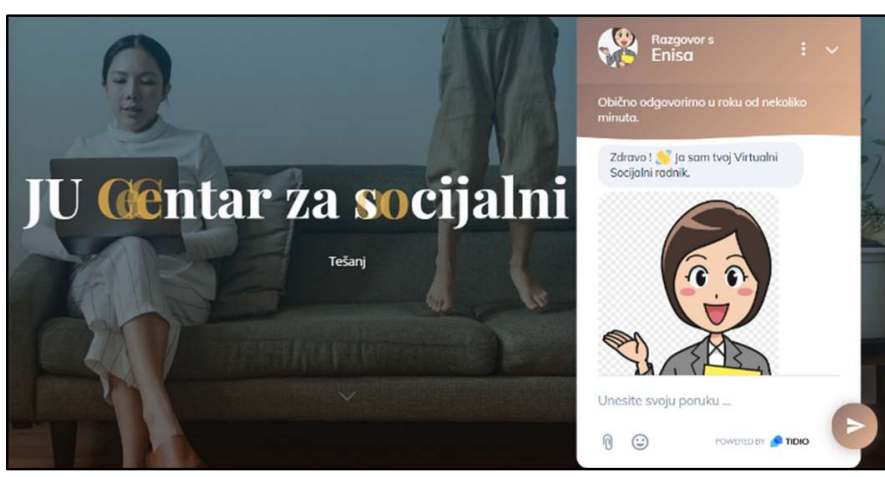

Figure 1. Wordpress webpage of Public Institution "Center for Social Work Tešanj" 
Simulating a conversation means that the chatbot plays a role that people usually play. Chatbots are designed for this so that they can understand commands in different phrases, similar to how people can. The advantage of this approach is that the user does not have to learn commands in advance, but can instead express them in a way similar to the way he/she communicates. The chatbot developed in this work is designed to play the role of a personal assistant at the Public Institution "Center for Social Work Tešanj" and, as already mentioned, was developed as part of the wordpress page. The model of creating a website with a chatbot as an assistant in the work was compared for usability in relation to the current application of the website of the Public Institution "Center for Social Work Tešanj" by measuring some characteristics of usability: namely satisfaction, efficiency, and effectiveness.

Based on the Rules of Procedure [32], the questions were formed and offered to the user in a chatbot. The chatbot also offers a solution to these questions, and as well asks users additional questions in order to collect the necessary data related to their problem, so that they are immediately aware of the problem core and are able solve it as soon as possible.

\section{B. Chatbot Implementation}

The workflow of the chatbot refers to asking questions, selecting questions from the area of interest, after which, depending on the selection, the chatbot sends the user an answer, i.e., advice according to the law which is the next step one can take. Chatbot for social work consists of 4 modules:

Module 1. Greetings and entering the name and surname of the user;

Module 2. Offered questions in the field of social work and answers to the same;

Module 3. Asking additional questions related to the selected area in order to collect information from the users;

Module 4. Notification and forwarding of the interview to the social worker for further solving of the problem.

There are 8 questions and answers for the purpose of providing assistance to users and the diagram (flow chart) is given in Figure 2:

\section{Q.1. Who is entitled to a one-time financial} assistance?

The right to one-time and exceptional financial assistance can be exercised by persons and families in a state of social need, who due to special circumstances (e.g., natural disaster, loss of job, no income, and no family members who are legally obliged to support them, returned from treatment, and etc.) requires an appropriate form of protection.

Additional questions for the purpose of gathering information:

Q.1-1 Are you in a state of social need or any of the above circumstances?

Q.1-2 Have you ever asked for help at the Public Institution "Center for Social Work Tešanj”?

Q.1-3 Are you in isolation, hospitalized, or have you already come out of isolation?

Q.1-4 Do you have any close relatives who are not in isolation with whom the center could cooperate and help you?

Q.2. Who has the right to health care through the center for social work?

The right to health insurance through the Public Institution "Center for Social Work Tešanj" can be exercised by persons whose income per household member does not exceed $20 \%$ of the average salary earned in Federation of Bosnia and Herzegovina in the previous year and who cannot exercise this right on another basis.

Additional questions for the purpose of gathering information:

Q.2-1 Do you have health insurance? On what basis (employment, unemployment)?

\section{Q.2-2 Why do you not have health care?}

Q.2-3 Are you in isolation, hospitalized, or have you already come out of isolation?

Q.2-4 Do you have any close relatives who are not in isolation with whom the center could cooperate and help you?

Q.3. What rights does a person over age of 65 have at the Public Institution "Center for Social Work Tešanj”?

Persons over 65 years of age (men) and women over 60 years of age belong to a special category of people who can exercise the right at the center, if they have not exercised the right to pension or other income, and do not have close relatives who are legally obliged to support them. Those who belong to the category of the elderly have other rights such as the assistance of other people, the assistance of staff from center or non-governmental organizations, depending on the assistance they need. They also have the right to health care if they do not have it on some other basis, as well as to housing.

Additional questions for the purpose of gathering information:

Q.3-1 Do you know a person who needs help which falls into this category of seniors? 


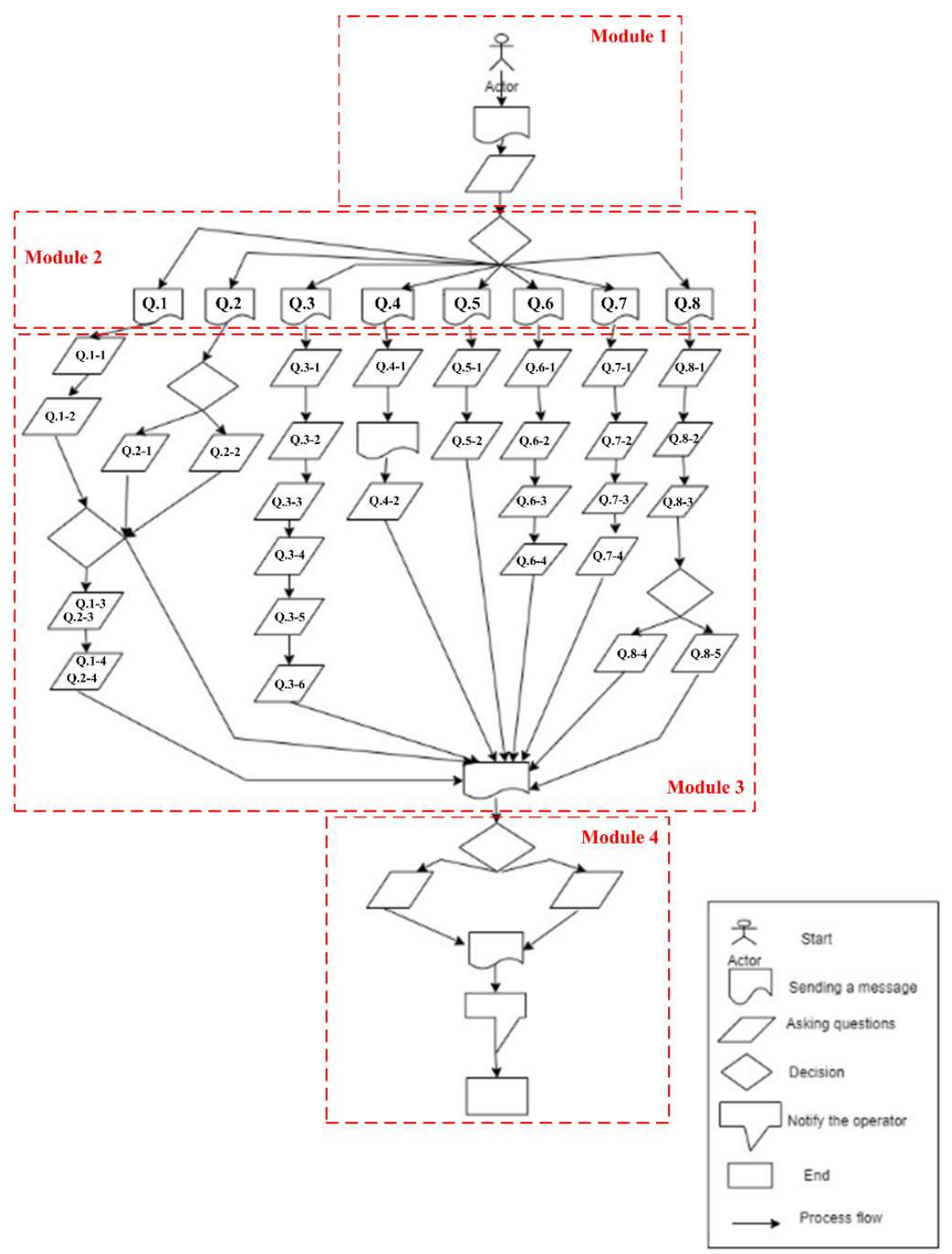

Figure 2. Chatbot flow chart

Q.3-2 Does the person have his/her own income, help from close relatives or other people?

Q.3-3 Does that person need medical help, medication (permanent therapy), food, or something else?

Q.3-4 Do you have information whether that person is a beneficiary of some rights in the center?

Q.3-5 Please insert the phone number of a person you want to help in order for us to check.

Q.3-6 Do you have something to add.

Q.4. I want a divorce, what is the first step?

If you have minor children, before initiating the divorce procedure, it is necessary to perform the procedure of mediation in the divorce at the Public Institution "Center for Social Work Tešanj". The purpose of mediation is to remedy the causes that led to the decision to divorce, eventual reconciliation, or to reach a parental agreement on the trust of children, contact, and maintenance of minor children.

Additional questions for the purpose of gathering information:

Q.4-1 Does your partner agree with the divorce and have you agreed, i.e., made an amicable agreement on trust, contact, and maintenance of minor children?

If you reside in the municipality of Tešanj, please, in addition to the application that you will download here on the page, also collect the following: Citizen Identification Protection System (CIPS), birth certificates for children, your wedding certificate.

Q.4-2 Write us a short story that prompted you to divorce!

Q.5. My ex-husband doesn't let me see our child, what should I do? 
As it is determined by a final court decision, the manner and time of maintaining contact with a minor child has the right and possibility to address the competent court with a proposal for the execution of the said judgment. If there is no final court judgment on contacting parents and children, it is necessary to file a lawsuit with the competent court to establish contact with the child because exercising the right to the same is within the jurisdiction of the court that makes the decision.

Additional questions for the purpose of gathering information:

Q.5-1 Do you have a final judgment? (If the final judgment regulates contact, apply to the competent court to comply with the judgment);

Q.5-2 Did your problem with contacting children arise during the pandemic? (If the contact problem did not exist before the pandemic, we must warn you of the current restrictions on the movement of children imposed by law related to the pandemic.)

Q.6. A parent does not pay child support after a divorce, what should I do?

After a final court decision determining the amount of the maintenance obligation for the parent of a minor child, he/she is obliged to act in accordance with the said decision. In the event that a parent does not comply with the obligation to pay, the other parent submits a proposal to the competent court for the execution of the said judgment.

Additional questions for the purpose of gathering information:

Q.6-1 Have you been granted alimony by a final judgment?

Q.6-2 Did your ex-partner pay alimony before the pandemic, i.e., was the current problem caused by the COVID-19 pandemic?

Q.6-3 Do you have information on whether your expartner has currently lost his/her job? need?

Q.6-4 Are you an unemployed person in a state of social

Q.7. Is it better to report violence to the Police Directorate or the Public Institution "Center for Social Work Tešanj"?

In high-risk situations, be sure to call the police first. In any case, the police are obliged to inform the Public Institution "Center for Social Work Tešanj", and the Center is obliged to get involved in working with the family. Contact police station Tešanj: 032 / 650 - 014 or 122.

Additional questions for the purpose of gathering information:
Q.7-1 Have you already contacted the Center for Social Work or the Police Directorate for Domestic Violence?

Q.7-2 Is it violence against children?

Q.7-3 How long has the violence been going on?

Q.7-4 Did domestic violence occur during the pandemic?

Q.8. Who initiates the procedure for deprivation of legal capacity?

A proposal for deprivation of legal capacity is submitted by relatives or social worker ex officio when, based on medical documentation and the user's behavior, one assesses that his/her rights and interests are endangered, that his/her behavior endangers himself/herself and the environment in which he/she lives, and that he/she is unaware of his/her behavior and actions. During the procedure, a decision of the center appoints a guardian who will protect the interests of the users in court.

Additional questions for the purpose of gathering information:

Q.8-1 Have you previously addressed the Center for Social Work with a proposal for deprivation of legal capacity?

Q.8-2 Has the decision of the Center for Social Work appointed a guardian for the person for whom you want to initiate the procedure of deprivation of legal capacity?

Q.8-3 Does the person have a regulated personal disability allowance and someone else's care?

Q.8-4 Does the person have the supervision, care or assistance of others?

Q.8-5 If a person had the help of another person, did the situation change or become more difficult due to the pandemic?

\section{End-user Survey on Social Work Chatbot Usage}

The end-user survey on social work chatbot has been conducted on a representative sample (social workers and users) and serves to give information on the justification of its usage in social work tasks. Therefore, the main objective of the study is to show the actual position on the use of social work chatbots. A total of 40 participants were surveyed in 30 days period (from $5^{\text {th }}$ May 2021 to $5^{\text {th }}$ June 2021). After testing the proposed social work chatbot, participants were asked to give their opinion regarding the usage of the chatbot.

The end-user survey consists of two parts: the sociodemographic questions and statements for evaluation of 
acceptance and usage motivation. The 16-item questionnaire is given in Table 1.

Table 1. End-user Survey Questionnaire

\begin{tabular}{|c|c|}
\hline Question & Offered answering option \\
\hline 1. What is your gender? & $\begin{array}{ll}- & \text { Male } \\
- & \text { Female }\end{array}$ \\
\hline 2. What is your age? & $\begin{array}{ll}- & \text { Younger age }(18-31) \\
- & \text { Middle age }(32-65) \\
\text { - } & \text { Third age }(66+) \\
\end{array}$ \\
\hline $\begin{array}{l}\text { 3. What is the level of your } \\
\text { education? }\end{array}$ & $\begin{array}{ll}- & \text { Faculty degree } \\
- & \text { High school degree } \\
- & \text { Elementary school degree }\end{array}$ \\
\hline $\begin{array}{l}\text { 4. Are you familiar with the term } \\
\text { chatbot? }\end{array}$ & $\begin{array}{ll}- & \text { Yes } \\
\text { - } & \text { No }\end{array}$ \\
\hline $\begin{array}{l}\text { 5. How many times have you used } \\
\text { chatbots prior to this survey? }\end{array}$ & $\begin{array}{ll} & 1-3 \text { times } \\
\text { - } & 4-6 \text { times } \\
\text { - } & 7-10 \text { times } \\
\text { - } & 10+ \\
\text { - } & \text { Never } \\
\end{array}$ \\
\hline $\begin{array}{l}\text { 6. Does the current webpage of } \\
\text { Public Institution "Center for } \\
\text { Social Work Tešanj" offer all } \\
\text { necessary info? }\end{array}$ & $\begin{array}{ll}- & \text { Yes } \\
- & \text { No }\end{array}$ \\
\hline $\begin{array}{l}\text { 7. Do you think this system should } \\
\text { be used in social work? }\end{array}$ & $\begin{array}{ll}- & \text { Yes } \\
- & \text { No } \\
\end{array}$ \\
\hline $\begin{array}{l}\text { 8. Do you consider that the } \\
\text { chatbot implementation would } \\
\text { improve and ease the work of the } \\
\text { center? }\end{array}$ & $\begin{array}{ll}- & \text { Yes } \\
- & \text { No }\end{array}$ \\
\hline $\begin{array}{l}\text { 9. What would be the main } \\
\text { reasons of chatbot usage in social } \\
\text { work in extraordinary } \\
\text { circumstances? }\end{array}$ & $\begin{array}{l}\text { Providing fast and preliminary } \\
\text { responses to the frequent user } \\
\text { queries } \\
\text { - } \quad \text { Counselling/education } \\
\text { Inability to visit the center due to } \\
\text { the new pandemic situation } \\
\text { Collecting the data from users for } \\
\text { the purpose of more rapid solving of } \\
\text { their issues }\end{array}$ \\
\hline $\begin{array}{l}10 . \text { The usage of the chatbot } \\
\text { application is: }\end{array}$ & $\begin{array}{ll}- & \text { Easy } \\
- & \text { Comprehensible and simple } \\
\text { - } & \text { Reliable and efficient } \\
\end{array}$ \\
\hline $\begin{array}{l}\text { 11. If chatbots were used in social } \\
\text { work, do you think they would } \\
\text { ease the work of social workers in } \\
\text { terms of collecting the data from } \\
\text { the users and help the users in } \\
\text { getting faster responses to their } \\
\text { queries? }\end{array}$ & $\begin{array}{ll}- & \text { Yes } \\
\text { - } & \text { No }\end{array}$ \\
\hline $\begin{array}{l}\text { 12. How important do you } \\
\text { consider the following factors } \\
\text { while using the chatbot? (1- less } \\
\text { important, 5- highly important) }\end{array}$ & $\begin{array}{ll}- & \text { Security of information } \\
- & \text { Confidentiality of information } \\
\text { - } & \text { Ease of use } \\
\text { - } & \text { Speed of data obtaining } \\
\end{array}$ \\
\hline $\begin{array}{l}\text { 13. According to your opinion, } \\
\text { what are the limitation factors? }\end{array}$ & $\begin{array}{ll}\text { - } & \text { Unreliability of correct responses } \\
\text { - } & \text { Inability to cover all social work } \\
\text { domains } \\
\text { - } & \text { Lack of users' trust }\end{array}$ \\
\hline 14. What would you prefer? & $\begin{array}{l}\text { Waiting for social worker to take a } \\
\text { phone call in an increased work load } \\
\text { caused by COVID-19 pandemic } \\
\text { Instantly receiving the response } \\
\text { from chatbot }\end{array}$ \\
\hline $\begin{array}{l}\text { 15. Which of the following } \\
\text { options you consider a key one for } \\
\text { motivating the users to use this } \\
\text { system? }\end{array}$ & $\begin{array}{ll}\text { - } & \text { Information is a key to make the } \\
\text { - } & \text { system come alive } \\
\text { - } & \text { Usoper mutual communication } \\
\text { - } & \text { Facilitated access to desired } \\
\text { information by user }\end{array}$ \\
\hline $\begin{array}{l}\text { 16. Do you think this system can } \\
\text { be put in use in Bosnia and } \\
\text { Herzegovina? }\end{array}$ & $\begin{array}{ll}- & \text { No } \\
- & \text { Slowly, but not unreachable } \\
\text { - } & \text { We are not on that level }\end{array}$ \\
\hline
\end{tabular}

\section{- System can be rapidly developed}

\section{A. Socio-demographic part}

The first part of the survey provides the sociodemographic analysis of the participants, as well as general knowledge of chatbots and their usage.

According to the collected data, more than half of participants were female $(57.7 \%)$, while the remaining $42.5 \%$ were male. When it comes to age, we considered three age groups: younger (18-31), middle (32-65), and third age $(66+) .60 \%$ of respondents are from the first age group, $32.5 \%$ from the second, while only $7.5 \%$ falls into the third age group. In regards to education level, 57.7\% of participants have a faculty degree, $35 \%$ a high school degree, while $7.5 \%$ only elementary school.

$75 \%$ of participants declared they are familiar with the term chatbot, while the remaining $25 \%$ are not. In addition, $27.5 \%$ of participants declared they have used chatbots 1-3 times prior to this survey, $25 \%$ have never used them, 7.5\% used them 4-6 times, $17.5 \%$ used them 7-10 times, while the remaining percentage used it over 10 times. However, these statistics should be taken with reserve and caution given that it is the most probable that the most users have actually used chatbots, but they were not aware of it. It is hardly possible today to conduct affairs online and not use this type of communication channel.

\section{B. Evaluation statements part}

After analyzing the socio-demographic part of the questionnaire, this part is related to analysis of usage and acceptance of social work chatbot based on responses given by the participants.

When asked "Does the current webpage of Public Institution "Center for Social Work Tešanj" offer all necessary info?" (Question 6), 80\% of respondents answered that it does not provide the necessary information. Further on, when asked whether this kind of system (i.e., chatbot) should be utilized in social work tasks (Question 7), 97.5\% respondents answered that it should. Also, $97.5 \%$ of respondents answered that they think that usage of chatbots would improve and ease the work of the Center (Question 8). Furthermore, 97.5\% participants think that if chatbots were used in social work, they would ease the work of social workers in terms of collecting the data from the users and help the users in getting faster responses to their queries (Question 11).

Question which tends to find out what would be the main reason for the utilization of chatbots in social work facilities in extraordinary circumstances (Question 9) shows that $62.5 \%$ of participants think that is the provisioning of fast and preliminary responses to the frequent user queries, while $30 \%$ that it is 
counselling/education. Inability to visit the center due to the new pandemic situation is the reason for $70 \%$ of respondents, which is expected given that the purpose of the produced chatbot is to ease the work in extraordinary circumstances. In addition, collecting the data from users for the purpose of more rapid solving of their issues has been selected as a main reason for chatbot usage by $62.5 \%$ of participants.

Further on, our intention was to find out users' opinion regarding the usage of the chatbot application. Answers to Question 10, which covers that, showed that $43.6 \%$ of users consider this system comprehensible and simple, $35.9 \%$ consider it easy to use, while $20.5 \%$ think this chatbot is reliable and efficient. Also, we wanted to find out which factors are important for the user in terms of chatbot usage (Question 12). The results show that all considered factors, i.e., security, confidentiality, ease of use, and speed are of great importance to the surveyed participants (over 15 rates of 5 for each). When it comes to limitation factors (Question 13), lack of user's trust is the largest issue with $70 \%$ of users' responses. $37.5 \%$ of respondents think the chatbots have a limitation of being unable to cover all social work domains, while $22.5 \%$ think that the issue is unreliability of responses.

However, statistics related to Question 14 go in favor of chatbot usage in social work context. Namely, $90 \%$ of respondents would prefer to instantly receive the response from chatbot, rather than to wait for the social worker to take the call. In line with this are the collected answers for $15^{\text {th }}$ question. $50 \%$ of users responded that the key motivation factor for the usage of chatbots is facilitated access to information and $45 \%$ think that the information is the key to keep the system alive. Around $30 \%$ of users consider proper communication an important factor, and a bit over quarter think that user's satisfaction is crucial for motivation.

Finally, in context of implementing this technology into social work procedures in Bosnia and Herzegovina, $60 \%$ of participants think that chatbots can be used, but that the implementation is slow (Question 16). However, they do not consider it unreachable. $17.5 \%$ have the opinion that system can be rapidly developed, while $15 \%$ consider the country not being on that level. Only 7.5\% participants think that this kind of system is inadequate for Bosnia and Herzegovina's circumstances.

\section{Conclusion}

The use of digital solutions and ICTs in social work institution and practices in extraordinary situations such as this COVID-19 pandemic is inevitable if one tends to continue affairs in this domain. The conducted literature review showed that this topic has been addressed to a limited extent, especially when the applied technology is chatbot. Therefore, this paper aims to contribute to research community in this area.

Accordingly, we have developed and implemented a simple social work chatbot application and investigated its acceptance and willingness of users to use it in a concrete social work institution by conducting an enduser survey.

The main results of the end-user study show that chatbots as ICTs are highly welcome in social care institutions in both situations: extraordinary and ordinary. Users consider them as a solution to ease the work of social workers in terms of collecting the data from the users and help the users in getting faster responses to their queries. Also, they would rather instantly receive the response from chatbot, rather than to wait for the social worker to take the call. In other words, there is a good acceptance and motivation to use chatbots in this area of work.

This work may serve as one of first inputs to research community in analysis of usage of ICTs in social work practices in challenging times. It provided the results that justify the usage of ICTs in social work tasks and encourages their intensified usage.

Therefore, one can conclude that the usage of ICTs in general and chatbots in particular in social work domains has a bright and promising future. Namely, the advances offered by these solutions allow ease and acceleration of the process of providing social care in extraordinary circumstances, but in general as well. Their utilization will be even more represented with further development and representation of digital solutions based on AI.

\section{References}

[1] IT Brief, "Consumers turn to chatbots \& online messaging as COVID-19 bites," 2020. [Online]. Available: https://itbrief.com.au/story/consumers-turn-to-chatbotsonline-messaging-as-covid-19-bites

[2] D. Vargo, L. Zhu, B. Benwell and Z. Yan, "Digital technology use during COVID-19 pandemic: A rapid review," Human Behavior and Emerging Technologies, vol. 3, pp. 13-24, 2020.

[3] R. Khan and A. Das, "Introduction to chatbots," in Build better chatbots, Bangalore, India: Apress, ch.1, sec. 1, pp. $1,2017$.

[4] D. Jurafsky and J.H. Martin, "Dilogue Systems and Chatbots," in Speech and Language Processing: An Introduction to Natural Language Processing, Computational Linguistics, and Speech Recognition, Third Edition draft, Edinburgh, Scotland: Prentice Hall, ch. 26, sec. 2, pp. 491, 2008.

[5] A. Softić, J. Baraković Husić, A. Softić and S. Baraković, "Health chatbot: Design, implementation, acceptation and usage motivation," in Proceedings of $20^{\text {th }}$ International 
Symposium INFOTEH-JAHORINA, Sarajevo, Bosnia and Herzegovina, 2021.

[6] C. Chan and M. Holosko, "Technology for social work interventions," Oxford Bibliographies in Social Work, Oxford University Press, 2018.

[7] S. Berzin, J. Singer and C. Chan, "Practice innovation through technology in the digital age: A grand challenge for social work," Grand Challenges for Social Work Initiative Working Paper, no. 12, 2015.

[8] M. Benej, A. Cibrano, L. Goldkind, S.J. Kim, S. Matorin and S. Schwartz, "Maintaining client-centered practice in a computer-centered world: The place for technology in social work practice - challenges, opportunities, and future steps," Special issue: Social Work in Health Care, vol. 53, 2015.

[9] D. West and D. Heath, "Theoretical pathways to the future: Globalization, ICT and social work theory and practice," Journal of Social Work, vol. 11, pp. 209-221, 2011.

[10] E.D. Giffords, "The Internet and social work: The next generation," Families in Society: The Journal of Contemporary Social Services, vol. 90, pp. 413-418, 2009.

[11] A. Hill and I. Shaw, "Social work \& ICT," Thousand Oaks, CA: SAGE, 2011.

[12] S. Watling and J. Rogers, "Social work in a digital society," London: SAGE, 2012.

[13] L.W. Groshong and F. Mishna, "Entering the digital world: Cyber technology and clinical social work practice," Special issue: Clinical Social Work Journal, vol. 43, 2015.

[14] National Association of Social Workers (NASW), "NASW, ASWB, CSWE, \& CSWA Standards for technology in social work practice," Washington, DC: National Association of Social Workers, 2017.

[15] Australian Association of Social Workers (AASW), "Ethics and practice guideline: Social media, information and communication technologies: Part 1," Melbourne: Australian Association of Social Workers, 2013.

[16] AASW, "Ethics and practice guideline: Social media, information and communication technologies: Part 2," Melbourne: Australian Association of Social Workers, 2013.

[17] British Association of Social Workers (BASW), "BASW social media policy," Birmingham: British Association of Social Workers, 2013.

[18] NASW, "NASW, ASWB, CSWE, \& CSWA standards for technology in social work practice," Washington, DC: National Association of Social Workers, 2017.

[19] How Social Workers Use Technology, Our Lady of the Lake University, 2021. [Online]. Available: https://onlineprograms.ollusa.edu/resources/article/howsocial-workers-use-technology/

[20] B.S. Russell and C.R. Lincoln, "Reducing hostile parenting through computer-mediated parenting education," Children and Youth Services Review, vol. 73, pp. 66-73, 2017.

[21] T. Hanley, Z. Ersahin, A. Sefi and J. Hebron, "Comparing online and face-to-face student counselling: What therapeutic goals are identified and what are the implications for educational providers?," Journal of Psychologists and Counsellors in Schools, vol. 27, pp. 3754, 2017.

[22] C.M. Holmes and K.A. Kozlowski, "A preliminary comparison of online and face-to-face process groups," Journal of Technology in Human Services, vol. 33, pp. 241-262, 2017.

[23] L.S. Lawrence, "The group, the photograph, the wound, and the writing: How a social worker uses narrative medicine to facilitate groups," Smith College Studies in Social Work, vol. 86, pp. 45-57, 2016.

[24] N. De Vecchi, A. Kenny, V. Dickson-Swift and S. Kidd, "How digital storytelling is used in mental health: A scoping review," International Journal of Mental Health Nursing, vol. 25, pp. 183-193, 2016.

[25] D.E. Parrish, H.K. Oxhandler, J. F. Duron, P. Swank and P. Bordnick, "Feasibility of virtual reality environments for adolescent social anxiety disorder," Research on Social Work Practice, vol. 26, pp. 825-835, 2016.

[26] C. Chan and M.J. Holosko, "The utilization of social media for youth outreach engagement: A case study," Qualitative Social Work, vol. 16(2), pp. 680-697, 2017.

[27] C. Chan and M.J. Holosko, "An overview of the use of Mechanical Turk in behavioral sciences: Implications for social work," Research on Social Work Practice, vol. 26, pp. 441-448, 2016.

[28] L.M. East and C.B. Havard, "Mental health mobile apps: From infusion to diffusion in the mental health social system," JMIR Mental Health 2:e10, 2015.

[29] A. Parab, S. Palkar, S. Maurya and S. Balpande, "An intelligent career counselling bot-a system for counselling," International Research Journal of Engineering and Technology, vol. 4, pp. 2325-2330, 2017.

[30] E. Campana, "Chatbots come of age in a crises," KPMG, 2020.

[31] Tidio, 2021. [Online]. Available: https://www.tidio.com/

[32] Law on basics of social protection, protection of civil war victims and protection of families with children, Official Gazette of Canton Sarajevo, 38/14, 38/16, 44/17, 28/18, 2018. 